\title{
On the presence of a pustulated temnospondyl in the Lower Triassic of southern Brazil
}

Sérgio Dias-Da-Silva and Ana Luiza Ramos Ilha

Acta Palaeontologica Polonica 54 (4), 2009: 609-614 doi: http://dx.doi.org/10.4202/app.2008.0073

The fossil record of temnospondyls in South America has been greatly expanded in the last 10 years, increasing their overall significance. They occur in Argentina, Brazil, and Uruguay, and range from the Guadalupian to the Late Triassic. The Early Triassic temnospondyl record in southern Brazil is mainly composed of fragmentary specimens, usually represented by dermal skull bones from the Sanga do Cabral Formation. Some of these fragments were tentatively referred to Lydekkerinidae and Rhytidosteidae based on their characteristic ridge-grooved "spider-web" pattern of ornamentation. In this contribution we report, for the first time, a temnospondyl skull fragment with pustulated sculpturing pattern, which is tentatively ascribed to Plagiosauridae. This new record could indicate the presence of a new temnospondyl taxon for the Lower Triassic of South America.

Key words: Temnospondyli, Plagiosauridae, paleobiogeography, Sanga do Cabral Formation, Lower Triassic, western Gondwana.

Sérgio Dias-da-Silva [sergiosilva@unipampa.edu.br] and Ana Luiza

Ramos Ilha [annaluyza sm@hotmail.com], Centro de Ciências Rurais, Universidade Federal do Pampa, Campus de São Gabriel, Avenida Antônio Trilha, 1847, Bairro Centro, CEP 97.300-000, São Gabriel, Rio Grande do Sul, Brazil.

This is an open-access article distributed under the terms of the Creative Commons Attribution License (for details please see creativecommons.org), which permits unrestricted use, distribution, and reproduction in any medium, provided the original author and source are credited. 
